\title{
Kajian ukuran utama perahu katir (pumpboat) pada perikanan tuna hand line di Kota Bitung, Provinsi Sulawesi Utara
}

\author{
A study of the principal dimension of outrigger boat (pumpboat) in tuna hand line fishery in \\ Bitung City, North Sulawesi Province
}

\author{
AlsEn SiadAdi, ReVOls D.Ch. PAMIKIRAN* dan Fransisco P.T. PANGAlila \\ Program Studi Pemanfaatan Sumberdaya Perikanan, Fakultas Perikanan dan Ilmu Kelautan, \\ Universitas Sam Ratulangi, Manado 95115
}

\begin{abstract}
The objectives of this research were to get the general description of the boat with outrigger system (pumpboat) in tuna hand line fishery in Bitung City, North Sulawesi Province; and to find the mathematical relationship of among the principal dimension of the boat and the length of the outrigger system, and the relationship of the length of the boat (L) and propulsion engine (HP). The result showed that the length and beam (B) of the boat has a linear relationship of $\mathrm{B}=0.3584+0.0860(\mathrm{~L})$ and $\mathrm{r}=0.56$; the relationship of length and depth (D) of the boat is $\mathrm{D}=$ $0.1491+0.0775(\mathrm{~L})$ dan $\mathrm{r}=0.64$; the relationship between the length of the boat and the length of outrigger boom (Lob) is Lob $=2.4187+0.4609(\mathrm{~L})$ and $\mathrm{r}=0.63$; and the relationship between the length of the boat and the length of the outrigger float (Lof) is Lof $=0.9161+0.6402(\mathrm{~L})$ and $r=0.88$; and the relationship of the length of the boat and the height of pole $(\mathrm{Hpo})$ is $\mathrm{Hpo}=0.4520+0.3254(\mathrm{~L})$ and $\mathrm{r}=0.78$. The size of propulsion engine had, however, no clear relationship with the principal dimension of the boat.
\end{abstract}

Keywords: outrigger boat, pumpboat, outrigger system

\begin{abstract}
ABSTRAK
Tujuan penelitian ini adalah mengetahui deskripsi secara umum perahu katir (pumpboat) pada perikanan tuna hand line di Kota Bitung, Provinsi Sulawesi Utara; dan mengetahui hubungan antar ukuran utama perahu katir, ukuran utama panjang (L) dengan sistem katir, dan ukuran utama panjang dengan daya penggerak (HP). Hasil penelitian menunjukkan bahwa ukuran utama panjang dan lebar (B) mengikuti hubungan regresi linear dengan model persamaan matematis: $\mathrm{B}=0,3584+0,0860(\mathrm{~L})$ dan $\mathrm{r}=0,56$; hubungan antara ukuran panjang dan dalam (D) mengikuti hubungan regresi linear dengan persamaan matematis: $\mathrm{D}=0,1491+0,0775(\mathrm{~L})$ dan $\mathrm{r}=0,64$; hubungan antara panjang dengan sistem katir: antara panjang dan panjang outrigger boom (Lob) mengikuti persamaan matematis: $\mathrm{Lob}=2,4187+0,4609(\mathrm{~L})$ dan $\mathrm{r}=0,63$; dan hubungan panjang dengan panjang outrigger float (Lof) mengikuti persamaan metematis: Lof $=0,9161+0,6402(\mathrm{~L})$ dan $r=0,88$; dan hubungan antara panjang dengan tinggi tiang (Hpo) mengikuti persamaan matematis: Hpo $=0,4520+0,3254(\mathrm{~L})$ dan $\mathrm{r}=0,78$. Penggunaan besar tenaga pendorong perahu katir belum memiliki hubungan dengan ukuran utama perahu katir.
\end{abstract}

Kata-kata kunci: perahu katir, pumpboat, sistem katir

\section{PENDAHULUAN}

Menurut UU No. 21 Tahun 1992 tentang pelayaran, kapal didefinisikan sebagai kendaraan air dengan bentuk dan jenis apapun, yang digerakkan dengan tenaga mekanik, tenaga angin atau ditunda, termasuk kendaraan yang berdaya dukung dinamis, kendaraan di bawah permukaan

*Penulis untuk penyuratan; e-mail: rdolficp@yahoo.com air, serta alat apung dan bangunan terapung yang tidak berpindah-pindah.

Di samping jenis-jenis kapal yang sudah umum digunakan dalam kegiatan penangkapan ikan ini, sekarang kita juga mengenal satu jenis kapal dengan istilah perahu katir (pumpboat). Perahu katir dikenal sebagai salah satu jenis kapal perikanan yang mengoperasikan alat tangkap pancing. 
Kapal ini pada mulanya dibuat dan digunakan di Philipina, baik sebagai alat transportasi dan juga sebagai kapal penangkap ikan. Dalam perkembangan selanjutnya kapal ini telah tersebar ke berbagai daerah di Indonesia khususnya di daerah Bitung, dimana jumlahnya bertambah begitu cepat dan digunakan sebagai kapal penangkapan ikan tuna. Sebagai salah satu jenis kapal perikanan, informasi perahu katir ini, masih sangat kurang baik dari segi ukuran, pembuatan, maupun penggunaannya.

Perahu katir juga memiliki beberapa keunikan dibanding dengan kapal pada umumnya. Pertama, perahu katir memiliki tiang yang berdiri di tengahtengah geladak perahu yang berfungsi untuk menahan keseimbangan dari sistem katir (outrigger system). Kedua, perahu katir mempunyai haluan dan buritan yang berbeda dengan kapal-kapal. Keunikan dari perahu katir ini merupakan hal menarik untuk dikaji, terlebih dalam meningkatkan kemampuan (ability) perahu dalam menunjang kegiatan penangkapan ikan.

Berkaitan dengan hal ini, maka dibutuhkan informasi atau pengetahuan tentang ukuran-ukuran dari perahu ini sebagai dasar dalam mendesain atau meredisain perahu sehingga akan diperoleh ability yang baik. Berdasarkan hal ini, perlu dilakukan kajian tentang ukuran utama perahu katir di Bitung, sebagai upaya dalam menyiapkan informasi teknis tentang perahu katir ini.

\section{METODE PENELITIAN}

Objek dari penelitian ini adalah perahu katir yang ada di Kota Bitung, Provinsi Sulawesi Utara yang berjumlah 289 perahu. Dari jumlah ini telah diukur 93 perahu sebagai sampel.

\section{Alat yang digunakan}

Alat yang digunakan dalam penelitian ini adalah sebagai berikut: alat tulis, kamera, 2 buah meteran masing-masing berukuran 50 dan $100 \mathrm{~m}$, komputer yang dilengkapai dengan program Curve Expert versi 1.4 (Hyams, 2009) untuk analisis data dan program Canvas v.9.0.3 Profesional (Build, 2004) untuk menggabungkan gambar lebih dari satu.

\section{Metode pengambilan data}

Teknik pengambilan data primer dilakukan melalui pengamatan dan pengukuran secara langsung di lapangan, serta wawancara. Sedangkan data sekunder diperoleh dari Dinas Kelautan dan Perikanan Kota Bitung yang meliputi data jumlah dan ukuran perahu katir dan juga pengutipan informasi dari beberapa tulisan ilmiah sesuai dengan topik penelitian dan data sekunder mencakup koefesien bentuk kapal. Pengukuran meliputi ukuran utama dan ukuran sistem katir.

1. Ukuran Utama

a. LOA (Length Overall), panjang seluruh perahu katir yang diukur dari bagian paling ujung buritan hingga bagian paling ujung pada haluan.

b. B (Breath), lebar perahu katir yang diukur mulai dari sisi luar yang satu ke sisi lainnya.

c. D (Draft), dalam atau tinggi perahu katir yang diukur mulai dari dek terendah hingga ke bagian badan perahu katir terbawah.

2. Ukuran Sistim Katir

a. Lob (Length Outrigger Boom), panjang "bahateng" yang diukur dari sisi kanan ke kiri atau sebaliknya.

b. Lof (Length Outrigger Float), panjang pengapung yang diukur paling ujung pengapung dari posisi haluan ke buritan atau sebaliknya.

c. Loa (Length Outrigger Arm), lengan katir yang diukur dari ujung bahateng tempat dimana pertemuan antara ujung lengan katir dan bahateng ke pengapung atau sebaliknya.

d. Hpo (High pole) tinggi tiang geladak yang diukur dari paling bawah yang masuk dari geladak kapal sampai paling atas.

\section{Metode Analisis Data}

Metode analisis data dilakukan berdasarkan perumusan metematis hubungan antar ukuran utama yaitu $y=f(x)$, dimana variabel bebas $x$ adalah panjang perahu dan variabel tak bebas $\mathrm{y}$ yaitu: lebar perahu, dalam perahu, panjang bahateng, panjang pengapung, daya penggerak perahu dan tinggi tiang.

\section{HASIL DAN PEMBAHASAN}

\section{Deskripsi perahu katir secara umum}

Perahu katir dikenal sebagai salah satu jenis kapal perikanan yang sering digunakan oleh masyarakat Kota Bitung, Provinsi Sulawesi Utara untuk menangkap ikan tuna dengan alat tangkap pancing (tuna hand line). Kisaran ukuran utama dari perahu katir ini adalah: panjang $=9,60-17,18 \mathrm{~m}$; lebar $=0,80-1,95 \mathrm{~m}$; dalam $=0.64-1,74 \mathrm{~m}$; panjang bahateng $=5,54-11,25 \mathrm{~m} ;$ panjang 
pengapung $=6,30-12,20 \mathrm{~m}$; tinggi tiang $=2,89$ 5,50 m; dan tenaga penggerak $=8-65 \mathrm{HP}$.

\section{Hubungan antar ukuran utama perahu katir}

Hasil analisis hubungan antara panjang dengan lebar dan dalam mengikuti hubungan regresi linear dengan model persamaan matematis berturut-turut sebagai berikut: $\mathrm{B}=0,3584+0,0860(\mathrm{~L})$ dengan $\mathrm{r}$ $=0,56 ;$ dan $\mathrm{D}=0,1491+0,0775(\mathrm{~L})$ dengan $\mathrm{r}=$ 0,64 .

Pemetaan diagram sebaran dan kurva peramalan dari kedua hubungan ini disajikan pada Gbr. 1.

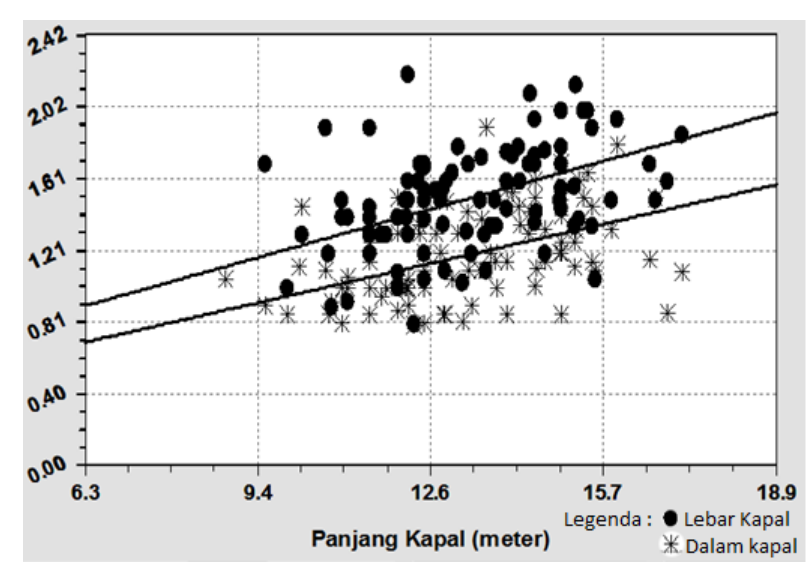

Gambar 1. Kurva hubungan antara panjang dan lebar, panjang dan dalam perahu katir di Bitung

Adanya hubungan antara ukuran panjang dan lebar, serta panjang dan dalam menunjukkan adanya pola ukuran utama kapal yang cenderung sama dari kapal yang diteliti sehingga dengan demikian hubungan ukuran utama kapal dalam bentuk persamaan matematis dapat digunakan sebagai penduga nilai antar ukuran utama kapal. Artinya berdasarkan persamaan hubungan matematis yang diperoleh dapat menjelaskan bahwa dengan bertambahnya ukuran panjang akan diikuti bengan bertambahnya nilai lebar sebesar 0,0860 kali dan nilai dalam sebesar 0,0775 kali dari setiap nilai perubahan panjang. Berdasarkan garis peramalan dan diagram sebaran data pada Gbr. 1 dapat dijelaskan bahwa nilai dalam perahu katir cenderung lebih kecil dari nilai lebar perahu katir.

\section{Hubungan ukuran utama dan sistem katir}

Hasil analisis regresi linear hubungan antara ukuran utama panjang dengan panjang bahateng adalah $\mathrm{Lob}=2,4187+0,4609(\mathrm{~L})$ dengan $\mathrm{r}=0,63$; dan hubungan antara ukuran utama panjang dengan panjang pengapung mengikuti hubungan regresi linear dengan model persamaan matematis Lof $=0,9161+0,6402(\mathrm{~L})$ dengan $r=0,88$; dan hubungan antara ukuran utama panjang dengan tinggi tiang mengikuti hubungan regresi linear dengan model $\mathrm{Hpo}=0,4520+0,3254(\mathrm{~L})$ dan $\mathrm{r}=$ 0,78 . Ketiga hubungan tersebut dapat dilihat pada Gbr. 2.

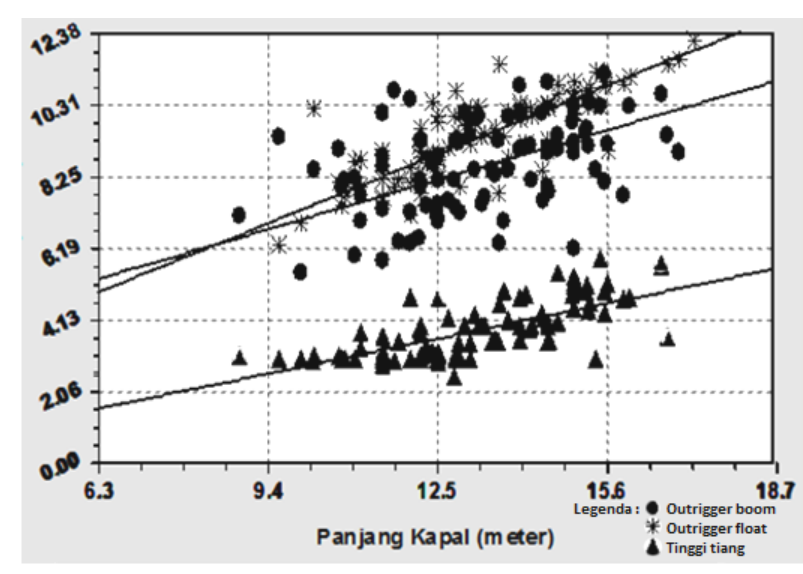

Gambar 2. Kurva hubungan antara panjang utama kapal dan panjang sistim katir dan tinggi tiang perahu katir di Bitung.

Adanya hubungan antara ukuran panjang utama dan sistem katir, antara panjang kapal dan bahateng, panjang kapal dan pengapung dan panjang kapal dengan tinggi tiang menunjukkan adanya pola ukuran sistem katir yang cenderung sama dari sistem katir yang diteliti sehingga dengan demikian hubungan ukuran utama kapal dan ukuran sistem katir dalam bentuk persamaan matematis dapat digunakan sebagai penduga nilai ukuran sistem katir dengan ukuran utama kapal. Artinya berdasarkan persamaan hubungan matematis yang diperoleh dapat menjelaskan bahwa dengan bertambahnya ukuran panjang kapal akan diikuti dengan bertambahnya nilai panjang bahateng sebesar 0,4609 kali, nilai panjang pengapung sebesar 0,6402 kali, dan nilai tinggi tiang sebesar 0,3254 kali. Berdasarkan pada garis peramalan dan diagram sebaran data pada Gbr. 2 dapat dijelaskan bahwa distribusi nilai panjang pengapung tersebut lebih besar dari panjang katir, dan distribusi nilai tinggi tiang lebih kecil dari kedua ukuran tersebut.

\section{Hubungan ukuran utama perahu katir dengan tenaga penggerak}

Model diagram sebaran data hubungan antara panjang kapal dan daya penggerak dipetakan 
seperti pada Gbr. 3. Menurut Soelistyo (1982), kondisi ini menunjukkan dan menjelaskan bahwa antara panjang kapal dan tenaga penggerak keadaan cenderung tidak memiliki hubungan. Keadan ini menjelaskan bahwa belum ada pola hubungan penyesuaian nilai antara besarnya daya penggerak yang digunakan dengan ukuran panjang perahu katir. Kenyataan ini diduga disebabkan karena penggunaan daya penggerak pada berbagai ukuran perahu katir hanya berdasarkan ketersediaan daya mesin yang ada di pasaran.

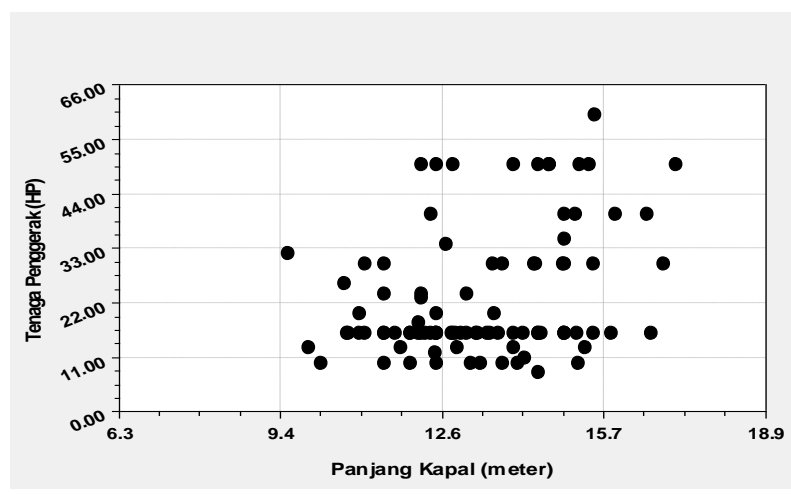

Gambar 3. Diagram sebaran data antara panjang kapal dengan tenaga penggerak perahu katir di Bitung

Semestinya penggunaan daya penggerak perahu katir akan lebih efektif dan efisien jika penggunaannya disesuaikan dengan ukuran perahu katir, hal ini sesuai dengan yang dinyatakan dalam Fyson (1985), bahwa ada hubungan antara ukuran kapal dengan daya penggerak yang digunakan.

\section{KESIMPULAN}

Dari hasil penelitian tentang kajian ukuran utama perahu katir dalam bidang perikanan tuna hand line di Bitung, Provinsi Sulawesi Utara dapat di tarik kesimpulan sebagai berikut :

1. Perahu katir merupakan perahu dengan konstruksi teknis yang terdiri dari bentuk haluan dan buritan yang mengarah ke atas permukaan sebagai salah satu karakteristik, bangunan atas kapal (superstruktur) yang berfungsi sebagai pelindung masuknya air ke kamar mesin, dek tertutup berfungsi sebagai pelindung masuknya air ke dalam perahu, dan sistem katir yang terdiri dari outrigger boom, outrigger float, outrigger arm, dan tiang yang berfungsi menambah kestabilan dari perahu katir.
2. Bertambahnya ukuran panjang akan diikuti oleh pertambahan ukuran lebar dan dalam perahu katir dengan mengikuti model linear sebagai berikut: $\mathrm{B}=0,3584+0,0860(\mathrm{~L})$ dengan $r=0,56$; dan $D=0,1491+0,0775(L)$ dan $r=0,64$

3. Bertambahnya ukuran panjang akan diikuti oleh pertambahan ukuran sistem katir yaitu panjang bahateng, panjang pengapung, dan tinggi tiang dengan mengikuti model matematis sebagai berikut: $\mathrm{Lob}=2,4187+0,4609(\mathrm{~L})$ dan $\mathrm{r}=0,63 ;$ Lof $=0,9161+0,6402(\mathrm{~L})$ dan $\mathrm{r}=$ 0,$88 ; \mathrm{Hpo}=0,4520+0,3254(\mathrm{~L})$ dan $\mathrm{r}=0,78$.

4. Bertambahnya ukuran panjang tidak selalu diikuti oleh pertambahan daya penggerak hal ini di sebabkan karena belum ada pola penyesuaian antara ukuran utama dengan daya penggerak perahu katir.

\section{DAFTAR PUSTAKA}

Anonim. 1985. Undang-Undang Perikanan No. 9 Tahun 1985. Bussiness News, Jakarta.

Anonim. 2009. Pengertian dari pumpboat dan arti pump dan boat. http: translate.google.co.id.wikipedia.org Wiki Jetboat, diakses tanggal 8 Februari 2011.

Ariyanto. 1986. Prosedur Penelitian: Suatu Pendekatan Praktis. Bina Aksara, Jakarta.

Build. 2004. Software Canvas v.9.0.3.

Fyson, F. (Editor). 1985. Design of Small Fishing Vessels. FAO. Fishing News Book. Ltd., Farhan-Surrey-England.

Handrianto. 1982. Pembuatan kapal gillnet 14,5 GT di PT.M. Jusdi. Tegal Jawa Tengah. Karya Ilmiah. IPB, Bogor.

Hyams, D. 2009. Software Curve Expert Versi 1.40.

Limpong, A. 1996. Studi tentang stabilitas dan kapasitas maksimum dari katir pada perahu tipe pelang. Skripsi. Fakultas Perikanan dan Ilmu Kelautan Unsrat. Manado.

Mandang, T. 2009. Kapasitas maksimum katir pada perahu tipe londe di semenanjung Utara Sulawesi. Jurnal Perikanan dan Kelautan V(1): 22-27.

Masengi, K., K. Takeda, K. Ueno, H.V. Dien, I.F. Mandagi, dan I.Y Paransa. 2000. Comparative studies of small purse seiner (pamo) at Bitung Municipality and Bolaang Uki waters of North Sulawesi. Internasional Symposium on Fisheries Science in Tropical Area, Proceedings of JSPS-DGHE.

Pangalila, J.C. 1995. Pengaruh sistem katir (outrigger system) terhadap stabilitas kapal ikan di Kelurahan Sario Tumpaan Kecamatan Sario Kotamadya Manado. Skripsi. Fakultas Perikanan Unsrat, Manado.

Purbayanto, A., H.B.H. Iskandar, S.H. Wisudo dan N. Yopi. 2004. Kajian teknis kemungkinan pengalihan pengaturan perijinan dari GT menjadi volume palka pada kapal ikan. Makalah. SemiLoka Paradigma Baru Pengelolaan Perikanan yang Bertanggungjawab dalam Rangka Mewujudkan Kelestarian Sumberdaya dan Manfaat Ekonomi Maksimal. Aryaduta Hotel, Jakarta.

Soelistyo. 1982. Pengantar Ekonometri I. Bagian Penerbitan Fak. Ekonomi UGM, Yokyakarta. 
Suzuki, O. 1980. Handbook for Scientists and Technologists. Training Departemant Southeast Asian Fisheries Development Center, Thailand.

Tindatu, C. 2005. Stabilitas statis kapal pole and line tipe funae di beberapa daerah di Provinsi Sulawesi Utara. Fakultas Perikanan dan Ilmu Kelautan Unsrat, Manado.
Undang-undang Republik Indonesia No. 21 Tahun 1992 Tentang Pelayaran.

Wahyono, A. 2011. Kapal Perikanan (Membangun Kapal Kayu). Balai Besar Pengembangan Penangkapan Ikan Direktorat Jenderal Perikanan Tangkap Kementerian Kelautan dan Perikanan. 